\title{
Thromboembolic disease in COVID-19 patients: A brief narrative review
}

\author{
Samhati Mondal ${ }^{1}$ (D), Ashley L. Quintili ${ }^{2}$ (D) Kunal Karamchandani ${ }^{3}$ (D) and Somnath Bose $^{4^{*}}$ (D)
}

\begin{abstract}
Corona virus 2 (SARS-CoV2/ Severe Acute Respiratory Syndrome Corona Virus 2) infection has emerged as a global health crisis. Incidence of thromboembolic disease is reported to be high in SARS-CoV2 disease and is seen in a multitude of organ systems ranging from cutaneous thrombosis to pulmonary embolism, stroke or coronary thrombosis sometimes with catastrophic outcomes. Evidence points towards a key role of thromboembolism, hypercoagulability and over production of proinflammatory cytokines mimicking a "cytokine storm" which leads to multiorgan failure. This brief narrative review highlights the pathophysiology and risk factors of thromboembolic disease and provides a framework for management of anticoagulation based on the current evidence.
\end{abstract}

Key words: COVID-19, thrombosis, thromboembolism, SARS-CoV2, management, coagulation

\section{Introduction}

The current coronavirus pandemic caused by the SARS$\mathrm{CoV} 2$ has rapidly emerged as a global health crisis. To date, over four million people have been affected by coronavirus disease 2019 (COVID-19) worldwide in about 188 countries and the number continues to grow [1]. In the United States alone, confirmed cases and deaths continue to rise, with current estimates at more than 1.9 million positive patients and over 110,000 deaths [1]. Symptoms range from asymptomatic or mild constitutional symptoms to pneumonia, sepsis and sometimes severe acute respiratory distress syndrome (ARDS) necessitating hospitalization and intensive care unit (ICU) admission [2]. The pivotal role of thrombo-inflammation and endothelial injury in the pathogenesis of the disease is being increasingly recognized. Overproduction of proinflammatory cytokines, including tumor necrosis factor (TNF), Interleukin (IL) -6 , IL-8, and IL-1 $\beta$, is believed to be the cause of what is being termed, "cytokine release syndrome" or "cytokine storm", a phenomenon which is

\footnotetext{
*Correspondence: sbose2@bidmc.harvard.edu

${ }^{4}$ Department of Anesthesiology, Critical Care and Pain Medicine, Beth Israel Deaconess Medical Center, Harvard Medical School, One Deaconess Road, Rosenberg 470, Boston, MA 02215, USA

Full list of author information is available at the end of the article
}

however not unique to this disease and has been noted in sepsis and sterile inflammation as well. This exaggerated cytokine response may lead to multiorgan failure and eventually death in some patients [3]. In addition to elevations in pro-inflammatory markers, hypercoagulability has been identified to be playing a key role determining prognosis in patients with COVID-19 [4]. In some observational series, thrombotic complications have been noted to be as high as $31 \%$ in patients requiring ICU admission and the risk persists even in patients on anticoagulation [5-8].

We searched for all published, readily accessible, peerreviewed, full articles written in English on PUBMED and EMBASE (between December $1^{\text {st }}, 2019$ to June $6^{\text {th }}$, 2020) related to thromboembolic complications seen in COVID -19 before writing this review. Majority of the articles included retrospective, observational, single or multicenter studies or case reports and correspondences.

In this brief narrative review, we discuss the pathophysiological mechanisms, clinical manifestations of thrombotic complications noted in patients with COVID19 and describe a pragmatic approach for management of anticoagulation strategies in these patients based on the currently available evidence. 


\section{Pathogenesis and risk factors}

COVID-19 shares multiple similarities with other well defined inflammatory states such as sepsis and sterile inflammation wherein simultaneous rise in pro and antiinflammatory cytokines are seen $[9,10]$. More pertinently, there is evidence of complement activation in COVID-19 by direct endothelial infection which includes release of anaphylotoxin C5a [11]. Complement activation as seen in COVID-19 not only drives neutrophil dysfunction leading to susceptibility to secondary infections but also activates the coagulation system thereby propagating a prothrombotic state. Coagulopathy associated with COVID-19 may be explained by the 'two way activation' theory, as seen by thrombocytopenia in critically ill patients (TICP) and the encompassing inflammatory and micro-thrombogenic responses that occur when endothelial insult takes place [12]. While the inflammatory pathway releases cytokines, the activation of microthrombotic pathway is mediated by release of large polymers of Von Willebrand factors (VWF). In the face of sepsis- induced endothelial injury, this reaction is aggravated causing enhanced platelet activation and consumption thrombocytopenia [13]. In contrast to the typical consumptive coagulopathy and disseminated intravascular coagulation (DIC) profile observed in sepsis, patients with COVID-19 typically have relatively normal coagulation and platelet profiles. Progression to DIC occurs in a minority of patients, rarely developing in survivors [4]. Therefore it seems that in keeping with Virchow's triad, thrombosis is driven both by the activation of coagulation factors and endothelium. In-situ immunethrombosis plays a key role to be the unifying mechanism explaining the micro and macrothrombotic manifestations of the disease. It should however be emphasized that in-situ microthrombosis has also been demonstrated in pulmonary and systemic tissue beds in ARDS and sepsis and therefore may not necessarily be unique to this population.

In addition to the factors mentioned above, these patients have additional risk factors for increased thrombosis, most notable among those being hypoxia, and immobility (made worse by frequent use of prone positioning) [14-16]. Although not systematically assessed, reduced staffing coupled with isolation precautions which limit frequent position changes and mobility may further predispose patients to a prothrombotic state.

\section{Clinical manifestations of thrombosis}

Since the beginning of the COVID-19 pandemic, serious thrombotic complications have been reported in infected patients especially those that are critically ill [7]. Lung autopsies from patients who died of COVID-19 revealed diffuse alveolar edema, thrombosis, formation of hyaline membrane resembling an ARDS like pattern [16-18].
The term MicroCLOTS (microvascular COVID-19 lung vessels obstructive thromboinflammatory syndrome) secondary to microvascular pulmonary thrombosis has been termed to describe the pulmonary manifestations of the disease [19]. In fact, micro-thrombosis, sometimes progressing to macro-thrombosis is not only limited to the lungs, other tissue beds have also been noted to be susceptible. Increasing reports of thrombotic events, including strokes, pulmonary embolism (PE), as well as, cutaneous and alveolar micro-thrombosis have been noted [18]. Various studies reported a wide range of thromboembolic complications including venous (PE, DVT) as well arterial thrombosis. Microthrombosis in lungs noted as high as $80 \%$ in autopsy of fatal COVID -19 [20]. Klok et al reported high incidence of VTE (31\%) leading to complications like PE (80\%), as well as arterial thrombosis (3.7\%) [7].

Table 1 \& 2 summarize the various thrombotic complications noted in COVID-19 patients as published as of June $6^{\text {th }}, 2020$ obtained by a literature search on PubMed and EMBASE using combinations of the following MeSH terms: COVID-19, SARS-COV2, novel corona virus, thrombosis, thromboembolic complications, pulmonary embolism.

Table 1 illustrates the observational studies and the most common thrombotic complications noted in these studies were venous thrombosis including PEs. There are also reports of arterial thrombosis including aortic graft thrombosis, mesenteric ischemia, coronary and cerebral thrombosis. Table 2 consists of isolated case reports, case series and correspondences. One unique finding of placental thrombosis has been reported as summarized in Table 2 which warrants further research of vertical transmission [40].

\section{Monitoring and diagnosis of VTE in critically ill patients with COVID-19}

Non-survivors of COVID-19 to have significant increases in fibrinogen degradation products (FDP), ddimer levels, as well as, prolongation of prothrombin time (PT), with $71.4 \%$ meeting diagnostic criteria for DIC [4]. It must however be noted that fibrinogen levels may rise initially as an acute phase reactant and such elevations may not necessarily be specific for COVID-19 [81]. Reports of elevated d-dimer levels and fibrinogen are increasingly prevalent in COVID-19 affected patients; leading many institutions to routinely monitor these values. These elevations appear to correlate with increased levels of inflammatory markers and may be indicators for disease severity in addition to thrombotic risk $[82,83]$.

A high index of clinical suspicion for thrombotic phenomenon and their sequela is warranted for prompt diagnosis. Clinical signs and symptoms of thrombosis 
Table 1 Thromboembolic complications with COVID 19 disease reported in single/multicenter studies

\begin{tabular}{|c|c|c|c|c|c|c|c|c|}
\hline Author & Country & $\begin{array}{l}\text { Venous } \\
\text { thromboembolism } \\
\text { - (\%) }\end{array}$ & $\begin{array}{l}\text { Pulmonary } \\
\text { embolism } \\
\text { percentage \% } \\
\text { or } \mathrm{N}\end{array}$ & $\begin{array}{l}\text { Arterial } \\
\text { thromboembolism } \\
\text { percentage (\%) }\end{array}$ & $\begin{array}{l}\text { Stroke } \\
\text { percentage } \\
(\%)\end{array}$ & $\begin{array}{l}\text { Acute coronary } \\
\text { syndrome } \\
\text { percentage (\%) }\end{array}$ & $\begin{array}{l}\text { Mesenteric/ } \\
\text { bowel Ischemia } \\
\text { percentage (\%) }\end{array}$ & $\begin{array}{l}\text { Limb } \\
\text { Ischemia } \\
\text { percentage } \\
(\%)\end{array}$ \\
\hline $\begin{array}{l}\text { Lodigiani } \\
\text { et al [21] }\end{array}$ & Italy & 4.4 & 2.8 & & 2.5 & 1.1 & & \\
\hline $\begin{array}{l}\text { Middeldorp } \\
\text { et al [22] }\end{array}$ & Netherlands & 20 & 6.6 & & & & & \\
\hline $\begin{array}{l}\text { Helms et al } \\
{[5]}\end{array}$ & France & & 16.7 & & & & 0.7 & 0.66 \\
\hline Llitjos [6] & Italy & 69 & 23 & & & & & \\
\hline Marone [23] & Italy & 53 & & & & & & \\
\hline $\begin{array}{l}\text { Wichmann } \\
\text { et al [24] }\end{array}$ & Germany & 53 & 33 & & & & & \\
\hline Cui et al [25] & China & 25 & & & & & & \\
\hline Klok et al [7] & Netherlands & $\begin{array}{l}27 \\
49\end{array}$ & $\begin{array}{l}13.5 \\
87\end{array}$ & 3.7 & & & & \\
\hline $\begin{array}{l}\text { Dolhnikoff } \\
\text { et al [20] }\end{array}$ & Brazil & & $\begin{array}{l}80 \\
\text { (Autopsy } \\
\text { finding) }\end{array}$ & & & & & \\
\hline $\begin{array}{l}\text { Ackermann } \\
\text { et al [26] }\end{array}$ & Germany & & $\begin{array}{l}57 \\
\text { Microthrombi } \\
\text { without } \\
\text { luminal } \\
\text { occlusion }\end{array}$ & & & & & \\
\hline $\begin{array}{l}\text { Demelo- } \\
\text { Rodriguez } \\
\text { et al [27] }\end{array}$ & Spain & 14.7 & & & & & & \\
\hline $\begin{array}{l}\text { Zhang et al } \\
\text { [28] }\end{array}$ & China & 46.1 & & & & & & \\
\hline $\begin{array}{l}\text { Ren at al } \\
{[29]}\end{array}$ & China & 85.4 & & & & & & \\
\hline $\begin{array}{l}\text { Stoneham } \\
\text { et al [30] }\end{array}$ & UK & 7.7 & & & & & & \\
\hline $\begin{array}{l}\text { Voicu et al } \\
\text { [31] }\end{array}$ & France & 46 & & & & & & \\
\hline $\begin{array}{l}\text { Desborough } \\
\text { et al [32] }\end{array}$ & UK & 15 & 8 & & & & & \\
\hline $\begin{array}{l}\text { Al-Samkari } \\
\text { et al [33] }\end{array}$ & USA & 6 & $N=10$ & 2.8 & & & & \\
\hline $\begin{array}{l}\text { Fraisse et al } \\
\text { [34] }\end{array}$ & France & 31.6 & & 8.4 & & & & \\
\hline
\end{tabular}

such as cutaneous manifestations ("COVID toe") [84], overt line thrombosis, arterial or venous clots, unexplained increase in oxygen requirement, or organ dysfunction should raise suspicion and prompt further investigation and/or discussion about therapeutic intervention [7] As new information becomes available, it appears increasingly important to routinely monitor platelet count, PT/aPTT, d-dimer, and fibrinogen to assist in anticipating and managing thrombotic complications. It has been reported that d-dimer levels cutoff of $1.5 \mu \mathrm{g} / \mathrm{mL}$ for predicting venous thromboembolic events has a sensitivity and specificity rate of $85 \%$ and $88.5 \%$ respectively and a negative predictive value of $94.7 \%$ [25]. Nonetheless, decisions for initiation of therapeutic anticoagulation should not be based solely on arbitrary d-dimer levels.

Use of viscoelastrometric tests such as Rotational thromboelastometry (ROTEM) could also be used as an important monitoring tool. Short clot formation time (CFT) on INTEM (type of ROTEM to detect Intrinsic pathway abnormality) and EXTEM (type of ROTEM to detect Extrinsic pathway abnormality) and increased maximum clot firmness (MCF) on INTEM, EXTEM, FIBTEM (type of ROTEM to detect fibrinogen 
Table 2 Thromboembolic complications with COVID 19 disease reported as case reports/case series/ correspondences

\begin{tabular}{|c|c|c|c|c|c|c|c|c|}
\hline Author & Country & $\begin{array}{l}\text { Venous } \\
\text { thromboembolism } \\
\text { (N) }\end{array}$ & $\begin{array}{l}\text { Pulmonary } \\
\text { embolism } \\
\text { numbers (N) }\end{array}$ & $\begin{array}{l}\text { Arterial } \\
\text { thromboembolism } \\
\text { numbers (N) }\end{array}$ & $\begin{array}{l}\text { Stroke } \\
\text { numbers } \\
\text { (N) }\end{array}$ & $\begin{array}{l}\text { Acute coronary } \\
\text { syndrome } \\
\text { numbers (N) }\end{array}$ & $\begin{array}{l}\text { Mesenteric/ } \\
\text { bowel Ischemia } \\
\text { numbers (N) }\end{array}$ & $\begin{array}{l}\text { Limb } \\
\text { Ischemia } \\
\text { numbers } \\
(\mathrm{N})\end{array}$ \\
\hline $\begin{array}{l}\text { Le Berre } \\
\text { et al [35] }\end{array}$ & France & 1 & 1 & $\begin{array}{l}1 \\
\text { (Aortic thrombosis) }\end{array}$ & & & & \\
\hline $\begin{array}{l}\text { Baldacini M } \\
\text { et al [36] }\end{array}$ & France & & & $\begin{array}{l}1 \\
\text { (Arterial } \\
\text { thrombosis) }\end{array}$ & & & & \\
\hline $\begin{array}{l}\text { Giacomelli } \\
\text { et al [37] }\end{array}$ & Italy & & & $\begin{array}{l}1 \\
\text { (Acute aortic graft } \\
\text { thrombosis) }\end{array}$ & & & & \\
\hline $\begin{array}{l}\text { Lacour et al } \\
\text { [38] }\end{array}$ & France & & & & & 1 & & \\
\hline $\begin{array}{l}\text { de Barry } \\
\text { et al [39] }\end{array}$ & France & 1 & & & & & 1 & \\
\hline $\begin{array}{l}\text { Mulvey et al } \\
\text { [40] }\end{array}$ & USA & & & $\begin{array}{l}5 \\
\text { (Placental } \\
\text { intravascular } \\
\text { thrombosis) }\end{array}$ & & & & \\
\hline $\begin{array}{l}\text { Griffin et al } \\
\text { [41] }\end{array}$ & USA & & 3 & & & & & \\
\hline $\begin{array}{l}\text { Zhou et al } \\
\text { [42] }\end{array}$ & China & 1 & & $\begin{array}{l}1 \\
\text { (Atherosclerosis } \\
\text { obliterans) }\end{array}$ & & & & \\
\hline $\begin{array}{l}\text { Zhou et al } \\
\text { [43] }\end{array}$ & China & 1 & & & 1 & & & \\
\hline $\begin{array}{l}\text { Dominguez- } \\
\text { Erquicia et al } \\
\text { [44] }\end{array}$ & Spain & & & & 1 & & & \\
\hline $\begin{array}{l}\text { Martinelli } \\
\text { et al [45] }\end{array}$ & Italy & & 1 & & & & & \\
\hline $\begin{array}{l}\text { Bozzani et al } \\
\text { [46] }\end{array}$ & Italy & 3 & & & & & & \\
\hline $\begin{array}{l}\text { Poggiali et al } \\
{[47]}\end{array}$ & Italy & 2 & 1 & & & & & \\
\hline $\begin{array}{l}\text { Hughes et al } \\
\text { [48] }\end{array}$ & UK & $\begin{array}{l}1 \\
\text { (Cerebral venous } \\
\text { sinus thrombosis) }\end{array}$ & & & & & & \\
\hline $\begin{array}{l}\text { Kashi et al } \\
\text { [49] }\end{array}$ & France & & & 7 & & & & \\
\hline $\begin{array}{l}\text { Garaci et al } \\
{[50]}\end{array}$ & Italy & 1 & 1 & & & & & \\
\hline Lax et al [51] & Austria & & $\begin{array}{l}11 \\
\text { (Postmortem } \\
\text { autopsy } \\
\text { finding) }\end{array}$ & & & & & \\
\hline $\begin{array}{l}\text { Mestres et al } \\
\text { [52] }\end{array}$ & Spain & & & 4 & & & & \\
\hline $\begin{array}{l}\text { Gomez- } \\
\text { Arbelaez } \\
\text { et al [53] }\end{array}$ & Spain & 1 & 1 & 2 & 2 & & & 1 \\
\hline $\begin{array}{l}\text { Davoodi } \\
\text { et al [54] }\end{array}$ & Iran & 1 & & & & & & \\
\hline $\begin{array}{l}\text { Viguier et al } \\
\text { [55] }\end{array}$ & France & & & & 1 & & & \\
\hline
\end{tabular}


Table 2 Thromboembolic complications with COVID 19 disease reported as case reports/case series/ correspondences (Continued)

Author

Country

Venous
thromboembolism

(N)

Pulmonary

embolism

numbers (N)

Arterial
thromboembolism
numbers $(\mathrm{N})$

numbers (N)

$\begin{array}{ll}\text { Stroke } & \text { Acute coronary } \\ \text { numbers } & \text { syndrome }\end{array}$

(N)
Mesenteric/

bowel Ischemia

numbers $(\mathrm{N})$
Limb

Ischemia

numbers

(N)

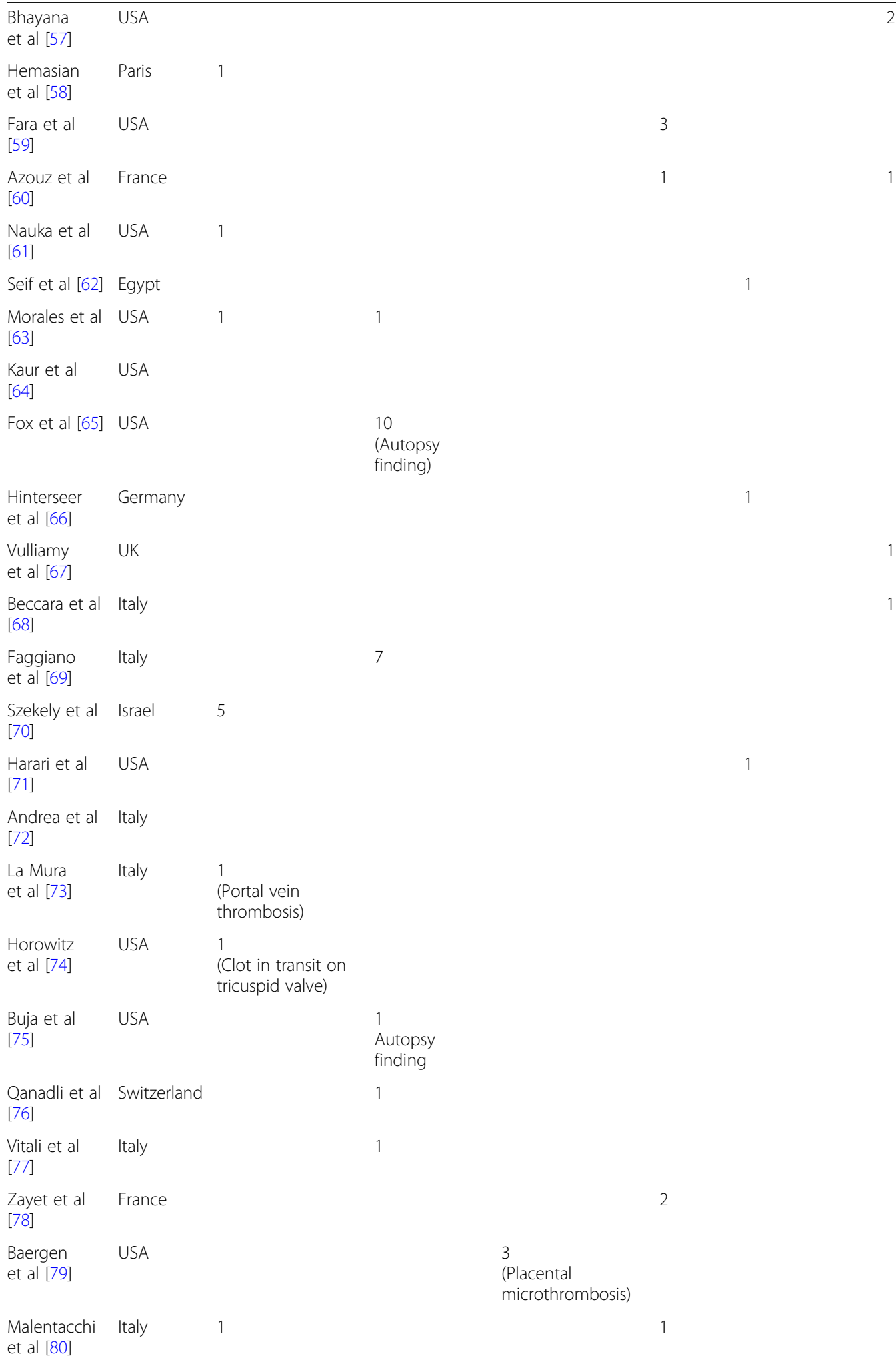

1 Autopsy finding

1 1 
abnormality) indicate hypercoagulation and potential for thrombogenesis [85]. Similarly, Thromboelastography (TEG) directed assessment of hypercoagulation status (short R, K and increased $\mathrm{K}$ angle and MA) can be predictive of thromboembolism [86].

Dugar and colleagues recently reported a high incidence of spontaneous echo contrast (SEC) in patients as noted on ultrasound examination of venous system while placing central line which could be precursors for venous thromboembolism (VTE). Their findings suggest the potential role of point-of-care ultrasound (POCUS) as a surveillance tool for early detection of patients at higher risk for thrombotic events [87].

\section{Management of anticoagulation}

The optimal approach to management of anticoagulation in these patients remains unclear in absence of well conducted trials. There remains major uncertainty in the optimal management of immune-thrombosis as commonly seen in COVID-19. Current strategies are heavily influenced by observational reports, case series and empirical institutional protocols. In asymptomatic and mildly symptomatic patients who do not require hospital admission, ambulation should continue to be the mainstay of thromboprophylaxis. It is advisable to institute, at minimum, prophylactic anticoagulation in admitted patients without clinical contraindications $[7,88]$.
Unfractionated heparin and low molecular weight heparin (LMWH) have been successfully used in these patients both prophylactically and therapeutically $[89,90]$. Higher doses should be considered for those with higher risk patients (eg, obese, active malignancy, prolonged immobility or recent surgery). As a caveat, it must be noted a high incidence of VTE has been noted even on patients on either prophylactic and therapeutic anticoagulation which makes routine surveillance extremely important $[5,6]$.

In addition to the usual indications such as obesity or active malignancy where higher intensity dosing of prophylactic anticoagulation may be warranted, patients with COVID-19 who demonstrate SEC on surveillance imaging may be considered for augmented dosing although high quality data to support routine use of this strategy is currently unavailable. Although some retrospective studies have demonstrated systemic anticoagulation to be associated with improved outcomes in hospitalized patients the conclusions of such observational studies should be interpreted cautiously in the context of limitations such as incomplete adjustment for confounders and specifically "immortal time bias" [91]. As such data from small observational studies should not be used to guide institutional guidelines in the absence of robust data to suggest a favorable risk benefit profile for such strategies. Figure 1 provides a pragmatic

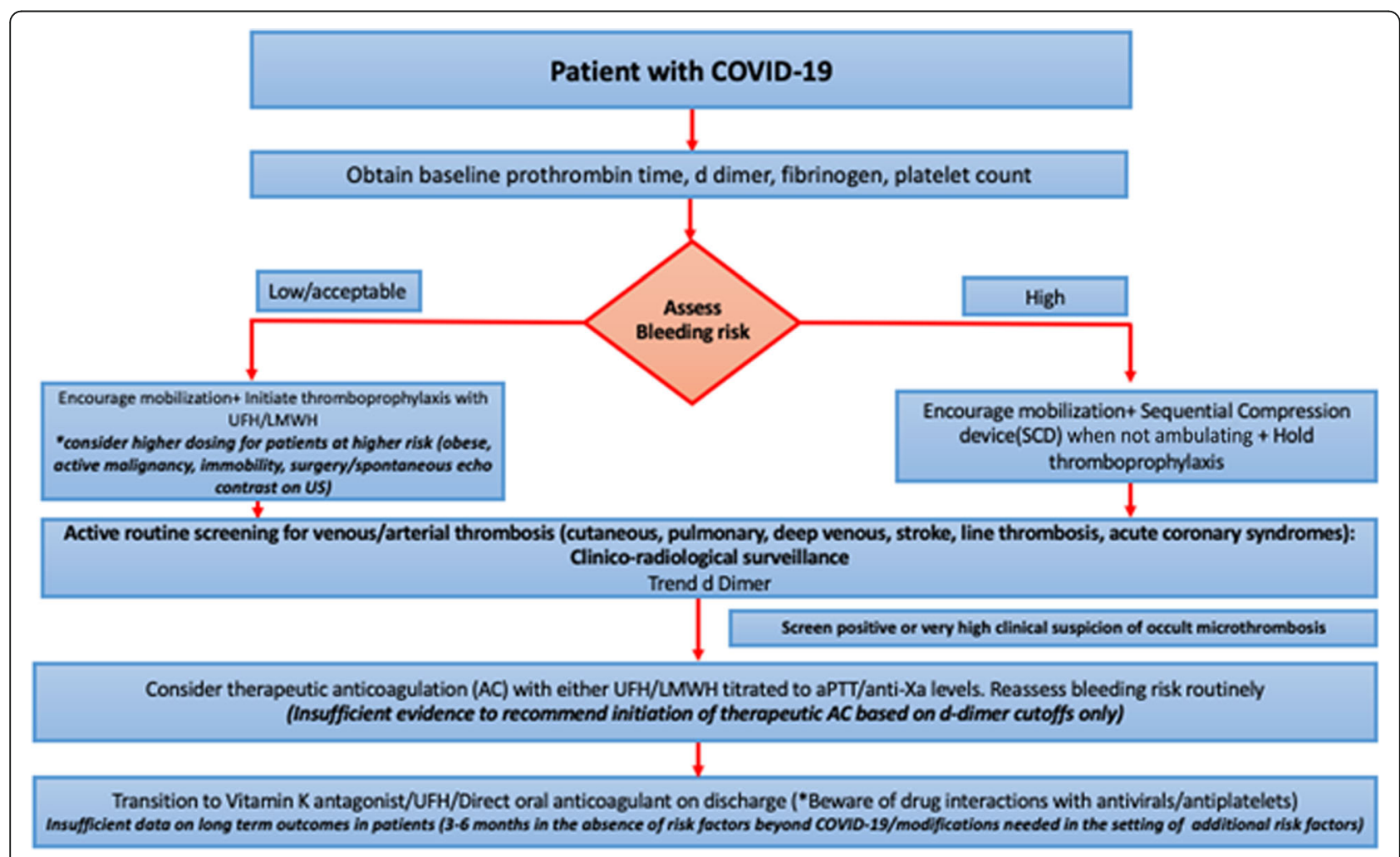

Fig. 1 Algorithm for the management of anticoagulation in patients hospitalized with COVID-19 
algorithm for the management of anticoagulation in a patient hospitalized with COVID-19 disease based on the limited available evidence.

Besides COVID-19, these patients have multiple other risk factors for development of thrombosis as described above. ICU patients positive for COVID-19 with elevated d-dimer levels and/or clinico-radiological suspicion for thrombosis as noted above should be considered for therapeutic anticoagulation only after careful assessment of their bleeding risk. Choice of agent should be discussed via interdisciplinary consultation and agents selected based on availability, end organ function and administration techniques which emphasize minimization of nursing contact. Active surveillance for thrombosis should continue even after initiation of therapeutic anticoagulation as clot progression has been demonstrated in patients with therapeutic levels of anticoagulation.

Patients with COVID-19 who experience a major thromboembolic event such as PE without any additional risk factors should be considered to have had a "provoked thromboembolic event" and may need 3-6 months of anticoagulation [92]. Minor episodes of DVTs should continue anticoagulation therapy for 2-6 weeks post hospital discharge [93]. The optimal duration of anticoagulation for those with risk factors, either new or preexisting risk factors (eg atrial fibrillation) may need to be modified according to established guidelines [88]. Long term follow up data on thrombotic risk post hospital discharger however remains unclear at this point. Antiviral therapies, which may be utilized in certain COVID-19 patients, are potent enzymes inhibitors and can slow down metabolism and prolong duration of action of many medications including direct oral anticoagulants so caution should be exercised regarding their concomitant dosing $[88,94]$. Patients should be comprehensively evaluated by the medical team and pharmacists to determine the most appropriate oral anticoagulant. Prophylactic anticoagulation should be considered in patients presenting with elevated $\mathrm{d}$-dimer levels but with no suspicion or evidence of thrombosis. Decisions on discharge therapy should be based on hospital protocols, patient specific factors, and multidisciplinary discussions regarding the risk benefit profile of chosen strategies.

\section{Special considerations}

The management of anticoagulation in COVID-19 patients extracorporeal membrane oxygenation (ECMO), is even more challenging [95]. Patients with refractory respiratory failure who fail traditional rescue therapies may require veno-venous (VV) ECMO, with a smaller proportion needing veno-arterial (VA) support $[95,96]$. Acquired von Willebrand disease, thrombocytopenia, and bleeding are known complications in patients on ECMO [97-100]. Studies have described the use of VV ECMO without anticoagulation to reduce bleeding risks, however, the artificial contact surface of ECMO circuit itself causes continuous activation of coagulation, creating a prothrombotic environment [101, 102]. The thrombotic risk is further accentuated in the presence of uninhibited COVID-19 diseases. Management of COVID-19 patients on ECMO is a balance between need for anticoagulation and risk of bleeding and therefore warrants close multidisciplinary discussions of risk benefit profile. A phase 2 clinical trial is currently underway to assess the efficacy of tPA (tissue plasminogen activator) as salvage therapy for severe ARDS patients (NCT04357730). The consistent demonstration of fibrin in the airspaces and lung parenchyma, along with fibrin-platelet microthrombi in the pulmonary vasculature suggests that plasminogen activators may have a role to limit ARDS progression and reduce ARDS-induced mortality. Currently, the routine use of tPA for salvage in severe ARDS patients is not recommended outside clinical trials until safety and efficacy of this treatment strategy is clearly established.

Pregnant patients with COVID-19 are at higher risk of thrombotic complications. Despite being mostly healthy and young, there are reports of pregnant patients with COVID-19 disease requiring intensive care admissions and being critically ill [103]. With immunocompromised status and physiological adaptive changes during pregnancy, pregnant women could be more susceptible to COVID-19 infection than the general population [104]. The thrombogenic risk of COVID-19 is further exacerbated by pregnancy which by itself is a hypercoagulable condition [105]. Such association of COVID-19 with pregnancy in terms of increasing thromboembolic risk warrants extra caution and requires a multidisciplinary approach to managing anticoagulation in these patients [88].

\section{Conclusion}

Systemic thrombosis is frequently associated with critically ill COVID-19 patients and may lead to fatal outcomes if not diagnosed and managed appropriately. Thrombotic risk commonly persists despite initiation of anticoagulation. Until more information is available, providers should consider prophylactic versus therapeutic anticoagulation based on a combination of patient specific criteria including laboratory results, imaging [88], clinical suspicion and careful balance of thrombotic and bleeding risks. Routine active surveillance guided by clinical and/or radiological assessment is recommended to either pre-empt or aid prompt diagnosis of macrothrombotic events which may be beneficial in guiding anticoagulation strategies. Larger, well designed prospective studies are urgently needed to further elucidate optimal management strategies to mitigate the thrombotic risks associated with COVID-19. 


\section{Acknowledgement}

The authors would like to acknowledge Dr Megan L Krajewski, MD for critical review and suggestions.

\section{Authors' contributions}

SB, SM: Conceptualization, design, interpretation of data, drafting of manuscript and revising for critically important intellectual content. ALQ, KK: Conceptualization, design, drafting of manuscript and revising for critically important intellectual content. All authors approve the final submitted version and agree to be accountable for all aspects of the work presented.

\section{Funding}

None. (SB received research support from NIH/Department of Defense unrelated to this project)

\section{Availability of data and materials}

Not applicable

\section{Ethics approval and consent to participate}

Not applicable

\section{Consent for publication}

Not applicable

\section{Competing interests}

None

\section{Glossary}

ARDS

Acute Respiratory Distress Syndrome

COVID-19

Coronavirus disease 2019

PE

DIC

Pulmonary embolism ECMO

Disseminated Intravascular Coagulation ROTEM

Extracorporeal Membrane Oxygenation EXTEM

Rotational Thromboelastometry

Extrinsic pathway of coagulation system abnormality assay using ROTEM INTEM ICU

Intrinsic pathway of coagulation system abnormality assay using ROTEM

Intensive Care Unit

Interleukin

MicroCLOTS

Microvascular COVID-19 Lung vessels Obstructive Thromboinflammatory Syndrome

TEG

Thromboelastography

TPA

Tissue plasminogen activator

TNF TICP

Tumor Necrosis Factor

Thrombocytopenia in Critically ill Patients SARS-CoV2 SEC

Severe Acute Respiratory Syndrome Corona Virus 2

Spontaneous Echo Contrast

VTE

Venous Thromboembolism

WF

Von Willebrand factors

\section{Author details}

'Department of Anesthesiology, University of Maryland School of Medicine, Baltimore, MD, USA. ²Department of Pharmacy, Penn State Health Milton S. Hershey Medical Center, Hershey, PA, USA. ${ }^{3}$ Department of Anesthesiology and Perioperative Medicine, Penn State Health Milton S. Hershey Medical Center, Hershey, PA, USA. ${ }^{4}$ Department of Anesthesiology, Critical Care and Pain Medicine, Beth Israel Deaconess Medical Center, Harvard Medical School, One Deaconess Road, Rosenberg 470, Boston, MA 02215, USA.

Received: 30 June 2020 Accepted: 12 August 2020

Published online: 14 September 2020

\section{References}

1. Medicine JHU. Corona Virus Resource Center. 04.28.2020 ed. Baltimore, USA 2020.

2. Grasselli G, Pesenti A, Cecconi M. Critical Care Utilization for the COVID-19 Outbreak in Lombardy, Italy: Early Experience and Forecast During an Emergency Response. JAMA 2020.

3. Meduri GU, Kohler G, Headley S, Tolley E, Stentz F, Postlethwaite A. Inflammatory cytokines in the BAL of patients with ARDS. Persistent elevation over time predicts poor outcome. Chest. 1995;108:1303-14.

4. Tang N, Li D, Wang X, Sun Z. Abnormal coagulation parameters are associated with poor prognosis in patients with novel coronavirus pneumonia. J Thromb Haemost. 2020;18:844-7.

5. Helms J, Tacquard C, Severac F, et al. High risk of thrombosis in patients with severe SARS-CoV-2 infection: a multicenter prospective cohort study. Intensive Care Med 2020

6. Llitjos JF, Leclerc M, Chochois C, et al. High incidence of venous thromboembolic events in anticoagulated severe COVID-19 patients. J Thromb Haemost. 2020.

7. Klok FA, Kruip M, van der Meer NJM, et al. Incidence of thrombotic complications in critically ill ICU patients with COVID-19. Thromb Res. 2020; 191:145-7.

8. Klok FA, Kruip M, van der Meer NJM, et al. Confirmation of the high cumulative incidence of thrombotic complications in critically ill ICU patients with COVID-19: An updated analysis. Thromb Res. 2020;191:148-50.

9. Yang Y SC, Li J, Yuan J, Yang $M$ et al. Exuberant elevation of IP-10, MCP-3 and IL-1ra during SARS-CoV-2 infection is associated with disease severity and fatal outcome. medRxiv 2020.

10. Faix JD. Biomarkers of sepsis. Crit Rev Clin Lab Sci. 2013;50:23-36.

11. Gao T HM, Zhang X, Li H, Zhu L et al. Highly pathogenic coronavirus N protein aggravates lung injury by MASP-2-mediated complement overactivation. medRxiv 2020.

12. Chang JC. Hemostasis based on a novel 'two-path unifying theory' and classification of hemostatic disorders. Blood Coagul Fibrinolysis. 2018;29: 573-84.

13. Chang JC. Sepsis and septic shock: endothelial molecular pathogenesis associated with vascular microthrombotic disease. Thromb J. 2019:17:10.

14. Gupta N, Zhao YY, Evans CE. The stimulation of thrombosis by hypoxia. Thromb Res. 2019:181:77-83.

15. Kollias A, Kyriakoulis KG, Dimakakos E, Poulakou G, Stergiou GS, Syrigos K. Thromboembolic risk and anticoagulant therapy in COVID-19 patients: emerging evidence and call for action. Br J Haematol. 2020.

16. Yao XH, Li TY, He ZC, et al. A pathological report of three COVID-19 cases by minimally invasive autopsies. Zhonghua Bing Li Xue Za Zhi. 2020;49:E009.

17. Barton LM, Duval EJ, Stroberg E, Ghosh S, Mukhopadhyay S. COVID-19 Autopsies. USA. Am J Clin Pathol: Oklahoma; 2020.

18. Magro C, Mulvey JJ, Berlin D, et al. Complement associated microvascular injury and thrombosis in the pathogenesis of severe COVID-19 infection: A report of five cases. Transl Res. 2020;220:1-13.

19. Ciceri F, Beretta L, Scandroglio AM, et al. Microvascular COVID-19 lung vessels obstructive thromboinflammatory syndrome (MicroCLOTS): an atypical acute respiratory distress syndrome working hypothesis. Crit Care Resusc. 2020;22:95-7.

20. Dolhnikoff M, Duarte-Neto AN, de Almeida Monteiro RA, et al. Pathological evidence of pulmonary thrombotic phenomena in severe COVID-19. J Thromb Haemost. 2020.

21. Lodigiani C, lapichino G, Carenzo L, et al. Venous and arterial thromboembolic complications in COVID-19 patients admitted to an academic hospital in Milan, Italy. Thromb Res. 2020;191:9-14. 
22. Middeldorp S, Coppens M, van Haaps TF, et al. Incidence of venous thromboembolism in hospitalized patients with COVID-19. J Thromb Haemost. 2020.

23. Marone EM, Rinaldi LF. Upsurge of deep venous thrombosis in patients affected by COVID-19: Preliminary data and possible explanations. J Vasc Surg Venous Lymphat Disord. 2020.

24. Wichmann D, Sperhake JP, Lutgehetmann M, et al. Autopsy Findings and Venous Thromboembolism in Patients With COVID-19: A Prospective Cohort Study. Ann Intern Med. 2020.

25. Cui S, Chen S, Li X, Liu S, Wang F. Prevalence of venous thromboembolism in patients with severe novel coronavirus pneumonia. J Thromb Haemost. 2020.

26. Ackermann M, Verleden SE, Kuehnel M, et al. Pulmonary Vascular Endothelialitis, Thrombosis, and Angiogenesis in Covid-19. N Engl J Med. 2020.

27. Demelo-Rodriguez P, Cervilla-Munoz E, Ordieres-Ortega L, et al. Incidence of asymptomatic deep vein thrombosis in patients with COVID-19 pneumonia and elevated D-dimer levels. Thromb Res. 2020;192:23-6.

28. Zhang L, Feng X, Zhang D, et al. Deep Vein Thrombosis in Hospitalized Patients with Coronavirus Disease 2019 (COVID-19) in Wuhan, China: Prevalence, Risk Factors, and Outcome. Circulation 2020.

29. Ren B, Yan F, Deng Z, et al. Extremely High Incidence of Lower Extremity Deep Venous Thrombosis in 48 Patients with Severe COVID-19 in Wuhan. Circulation. 2020.

30. Stoneham SM, Milne KM, Nuttal E, et al. Thrombotic risk in COVID-19: a case series and case-control study. Clin Med (Lond). 2020.

31. Voicu S, Bonnin P, Stepanian A, et al. High prevalence of deep vein thrombosis in mechanically ventilated COVID-19 patients. J Am Coll Cardiol. 2020.

32. Desborough MJR, Doyle AJ, Griffiths A, Retter A, Breen KA, Hunt BJ. Imageproven thromboembolism in patients with severe COVID-19 in a tertiary critical care unit in the United Kingdom. Thromb Res. 2020;193:1-4.

33. Al-Samkari H, Karp Leaf RS, Dzik WH, et al. COVID and Coagulation: Bleeding and Thrombotic Manifestations of SARS-CoV2 Infection. Blood. 2020.

34. Fraisse M, Logre E, Pajot O, Mentec H, Plantefeve G, Contou D. Thrombotic and hemorrhagic events in critically ill COVID-19 patients: a French monocenter retrospective study. Crit Care. 2020;24:275.

35. Le Berre A, Marteau V, Emmerich J, Zins M. Concomitant acute aortic thrombosis and pulmonary embolism complicating COVID-19 pneumonia. Diagn Interv Imaging. 2020;101:321-2.

36. Baldacini M, Pop R, Sattler $L$, et al. Concomitant hemorrhagic syndrome and recurrent extensive arterial thrombosis in a patient with COVID-19 and acute promyelocytic leukemia. Br J Haematol. 2020

37. Giacomelli E, Dorigo W, Fargion A, Calugi G, Cianchi G, Pratesi C. Acute thrombosis of an aortic prosthetic graft in a patient with severe COVID-19 related pneumonia. Ann Vasc Surg. 2020.

38. Lacour T, Semaan C, Genet T, Ivanes F. Insights for increased risk of failed fibrinolytic therapy and stent thrombosis associated with COVID-19 in STsegment elevation myocardial infarction patients. Catheter Cardiovasc Interv. 2020

39. de Barry O, Mekki A, Diffre C, Seror M, Hajjam ME, Carlier RY. Arterial and venous abdominal thrombosis in a 79-year-old woman with COVID-19 pneumonia. Radiol Case Rep. 2020.

40. Mulvey JJ, Magro CM, Ma LX, Nuovo GJ, Baergen RN. Analysis of complement deposition and viral RNA in placentas of COVID-19 patients. Ann Diagn Pathol. 2020;46:151530.

41. Griffin DO, Jensen A, Khan M, et al. Pulmonary Embolism and Increased Levels of d-Dimer in Patients with Coronavirus Disease. Emerg Infect Dis. 2020;26.

42. Zhou B, She J, Wang Y, Ma X. Venous thrombosis and arteriosclerosis obliterans of lower extremities in a very severe patient with 2019 novel coronavirus disease: a case report. J Thromb Thrombolysis. 2020.

43. Zhou B, She J, Wang Y, Ma X. A Case of Coronavirus Disease 2019 With Concomitant Acute Cerebral Infarction and Deep Vein Thrombosis. Front Neurol. 2020;11:296.

44. Dominguez-Erquicia P, Dobarro D, Raposeiras-Roubin S, Bastos-Fernandez G, Iniguez-Romo A. Multivessel coronary thrombosis in a patient with COVID19 pneumonia. Eur Heart J. 2020.

45. Martinelli I, Ferrazzi E, Ciavarella A, et al. Pulmonary embolism in a young pregnant woman with COVID-19. Thromb Res. 2020;191:36-7.

46. Bozzani A, Arici V, Franciscone MM, et al. Severe Acute Respiratory Syndrome Coronavirus 2 Infection and the Upper Limb Deep Vein Thrombosis Risk. Ann Vasc Surg. 2020.
47. Poggiali E, Bastoni D, loannilli E, Vercelli A, Magnacavallo A. Deep Vein Thrombosis and Pulmonary Embolism: Two Complications of COVID-19 Pneumonia? Eur J Case Rep Intern Med. 2020;7:001646.

48. Hughes C, Nichols T, Pike M, Subbe C, Elghenzai S. Cerebral Venous Sinus Thrombosis as a Presentation of COVID-19. Eur J Case Rep Intern Med. 2020; 7:001691.

49. Kashi M, Jacquin A, Dakhil B, et al. Severe arterial thrombosis associated with Covid-19 infection. Thromb Res. 2020;192:75-7.

50. Garaci F, Di Giuliano F, Picchi E, Da Ros V, Floris R. Venous cerebral thrombosis in COVID-19 patient. J Neurol Sci. 2020;414:116871.

51. Lax SF, Skok K, Zechner P, et al. Pulmonary Arterial Thrombosis in COVID-19 With Fatal Outcome: Results From a Prospective. Clinicopathologic Case Series. Ann Intern Med: Single-Center; 2020.

52. Mestres G, Puigmacia R, Blanco C, Yugueros X, Esturrica M, Riambau V. Risk of peripheral arterial thrombosis in COVID-19. J Vasc Surg. 2020.

53. Gomez-Arbelaez D, Ibarra-Sanchez G, Garcia-Gutierrez A, Comanges-Yeboles A, Ansuategui-Vicente M, Gonzalez-Fajardo JA. Covid-19-Related Aortic Thrombosis: A Report of Four Cases. Ann Vasc Surg. 2020.

54. Davoodi L, Jafarpour H, Taghavi M, Razavi A. COVID-19 Presented With Deep Vein Thrombosis: An Unusual Presenting. J Investig Med High Impact Case Rep. 2020;8:2324709620931239.

55. Viguier A, Delamarre L, Duplantier J, Olivot JM, Bonneville F. Acute ischemic stroke complicating common carotid artery thrombosis during a severe COVID-19 infection. J Neuroradiol. 2020

56. Rey JR, Valero SJ, Pinedo DP, Llorens JLM, Lopez-Sendon JL, Caro-Codon J. [COVID-19 and simultaneous thrombosis of two coronary arteries]. Rev Esp Cardiol 2020.

57. Bhayana R, Som A, Li MD, et al. Abdominal Imaging Findings in COVID-19: Preliminary Observations. Radiology. 2020;201908.

58. Hemasian H, Ansari B. First case of Covid-19 presented with cerebral venous thrombosis: A rare and dreaded case. Rev Neurol (Paris). 2020;176:521-3.

59. Fara MG, Stein LK, Skliut M, Morgello S, Fifi JT, Dhamoon MS. Macrothrombosis and stroke in patients with mild Covid-19 infection. J Thromb Haemost. 2020.

60. Azouz E, Yang S, Monnier-Cholley L, Arrive L. Systemic arterial thrombosis and acute mesenteric ischemia in a patient with COVID-19. Intensive Care Med. 2020.

61. Nauka PC, Oran E, Chekuri S. Deep venous thrombosis in a non-critically ill patient with novel COVID-19 infection. Thromb Res. 2020;192:27-8.

62. Seif S, Ayuna A, Kumar A, Macdonald J. Massive coronary thrombosis caused primary percutaneous coronary intervention to fail in a COVID-19 patient with ST-elevation myocardial infarction. Catheter Cardiovasc Interv. 2020

63. Morales $\mathrm{MH}$, Leigh $\mathrm{CL}$, Simon EL. COVID-19 infection with extensive thrombosis: A case of phlegmasia cerulea dolens. Am J Emerg Med. 2020

64. Kaur P, Qaqa F, Ramahi A, et al. Acute upper limb ischemia in a patient with COVID-19. Hematol Oncol Stem Cell Ther. 2020.

65. Fox SE, Akmatbekov A, Harbert JL, Li G, Quincy Brown J, Vander Heide RS. Pulmonary and cardiac pathology in African American patients with COVID19: an autopsy series from New Orleans. Lancet Respir Med. 2020.

66. Hinterseer M, Zens M, Wimmer RJ, et al. Acute myocardial infarction due to coronary stent thrombosis in a symptomatic COVID-19 patient. Clin Res Cardiol. 2020

67. Vulliamy $P$, Jacob S, Davenport RA. Acute aorto-iliac and mesenteric arterial thromboses as presenting features of COVID-19. Br J Haematol. 2020.

68. L AB, Pacioni C, Ponton S, Francavilla S, Cuzzoli A. Arterial Mesenteric Thrombosis as a Complication of SARS-CoV-2 Infection. Eur J Case Rep Intern Med. 2020;7:001690.

69. Faggiano P, Bonelli A, Paris S, et al. Acute pulmonary embolism in COVID-19 disease: Preliminary report on seven patients. Int J Cardiol. 2020.

70. Szekely Y, Lichter Y, Taieb P, et al. The Spectrum of Cardiac Manifestations in Coronavirus Disease 2019 (COVID-19) - a Systematic Echocardiographic Study. Circulation. 2020.

71. Harari R, Bangalore S, Chang E, Shah B. COVID-19 complicated by acute myocardial infarction with extensive thrombus burden and cardiogenic shock. Catheter Cardiovasc Interv. 2020.

72. Andrea V, Gianluca F, Rodolfo P, Paolo T, Alessandro P, Mauro G. Unheralded Lower Limb Threatening Ischemia in a COVID-19 Patient. Int J Infect Dis. 2020.

73. La Mura V, Artoni A, Martinelli I, et al. Acute Portal Vein Thrombosis in SARSCoV-2 Infection: A Case Report. Am J Gastroenterol. 2020. 
74. Horowitz JM, Yuriditsky E, Henderson IJ, Stachel MW, Kwok B, Saric M. Clot in Transit on Transesophageal Echocardiography in a Prone Patient with COVID-19 Acute Respiratory Distress Syndrome. CASE (Phila). 2020.

75. Buja LM, Wolf DA, Zhao B, et al. The emerging spectrum of cardiopulmonary pathology of the coronavirus disease 2019 (COVID-19): Report of 3 autopsies from Houston, Texas, and review of autopsy findings from other United States cities. Cardiovasc Pathol. 2020;48:107233.

76. Qanadli SD, Gudmundsson L, Rotzinger DC. Catheter-directed thrombolysis in COVID-19 pneumonia with acute PE: Thinking beyond the guidelines. Thromb Res. 2020;192:9-11.

77. Vitali C, Minniti A, Caporali R, Del Papa N. Occurrence of pulmonary embolism in a patient with mild clinical expression of COVID-19. Thromb Res. 2020;192:21-2.

78. Zayet S, Klopfenstein T, Kovacs R, Stancescu S, Hagenkotter B. Acute Cerebral Stroke with Multiple Infarctions and COVID-19, France, 2020. Emerg Infect Dis. 2020;26

79. Baergen RN, Heller DS. Placental Pathology in Covid-19 Positive Mothers: Preliminary Findings. Pediatr Dev Pathol. 2020;23:177-80.

80. Malentacchi M, Gned D, Angelino V, et al. Concomitant brain arterial and venous thrombosis in a COVID-19 patient. Eur J Neurol. 2020.

81. Ding $\mathrm{S}$, Lin $\mathrm{Q}$, Zhu T, et al. Is there a correlation between inflammatory markers and coagulation parameters in women with advanced ovarian endometriosis? BMC Womens Health. 2019;19:169.

82. Zhang L, Yan X, Fan Q, et al. D-dimer levels on admission to predict inhospital mortality in patients with Covid-19. J Thromb Haemost. 2020;18: 1324-9

83. Connors JM, Levy JH. COVID-19 and its implications for thrombosis and anticoagulation. Blood. 2020;135:2033-40.

84. Seirafianpour F, Sodagar S, Mohammad AP, et al. Cutaneous manifestations and considerations in COVID-19 pandemic: A systematic review. Dermatol Ther. 2020.

85. Spiezia L, Boscolo A, Poletto F, et al. COVID-19-Related Severe Hypercoagulability in Patients Admitted to Intensive Care Unit for Acute Respiratory Failure. Thromb Haemost. 2020;120:998-1000.

86. Panigada M, Bottino N, Tagliabue $P$, et al. Hypercoagulability of COVID-19 patients in Intensive Care Unit. A Report of Thromboelastography Findings and other Parameters of Hemostasis. J Thromb Haemost 2020.

87. Dugar S, Duggal A, Bassel A, Soliman M, Moghekar A. Spontaneous echo contrast in venous ultrasound of severe COVID-19 patients. Intensive Care Med. 2020.

88. Bikdeli B, Madhavan MV, Jimenez D, et al. COVID-19 and Thrombotic or Thromboembolic Disease: Implications for Prevention, Antithrombotic Therapy, and Follow-up. J Am Coll Cardiol. 2020.

89. Thachil J, Tang N, Gando S, et al. Type and dose of heparin in COVID-19. J Thromb Haemost. 2020.

90. Belen-Apak FB, Sarialioglu F. The old but new: Can unfractioned heparin and low molecular weight heparins inhibit proteolytic activation and cellular internalization of SARS-CoV2 by inhibition of host cell proteases? Med Hypotheses. 2020;142:109743.

91. Paranjpe I, Fuster V, Lala A, et al. Association of Treatment Dose Anticoagulation with In-Hospital Survival Among Hospitalized Patients with COVID-19. J Am Coll Cardiol. 2020.

92. Streiff MB, Agnelli G, Connors JM, et al. Guidance for the treatment of deep vein thrombosis and pulmonary embolism. J Thromb Thrombolysis. 2016;41: 32-67.

93. Kumar $\mathrm{P}$, Mediwake R, Rhead C. A matter of time: duration and choice of venous thromboprophylaxis in patients diagnosed with COVID-19. Br J Hosp Med (Lond). 2020;81:1-2.

94. Testa S, Prandoni P, Paoletti O, et al. Direct oral anticoagulant plasma levels striking increase in severe COVID-19 respiratory syndrome patients treated with antiviral agents. The Cremona experience J Thromb Haemost. 2020.

95. Marullo AG, Cavarretta E, Biondi-Zoccai G, et al. Extracorporeal membrane oxygenation for critically ill patients with coronavirus-associated disease 2019: an updated perspective of the European experience. Minerva Cardioangiol. 2020

96. Zochios V, Brodie D, Charlesworth M, Parhar KK. Delivering extracorporeal membrane oxygenation for patients with COVID-19: what, who, when and how? Anaesthesia; 2020.

97. Koeckerling D, Pan D, Mudalige NL, Oyefeso O, Barker J. Blood transfusion strategies and ECMO during the COVID-19 pandemic. Lancet Respir Med. 2020.
98. Lukito P, Wong A, Jing J, et al. Mechanical circulatory support is associated with loss of platelet receptors glycoprotein Ibalpha and glycoprotein VI. J Thromb Haemost. 2016;14:2253-60.

99. Horiuchi H, Doman T, Kokame K, Saiki Y, Matsumoto M. Acquired von Willebrand Syndrome Associated with Cardiovascular Diseases. J Atheroscler Thromb. 2019;26:303-14.

100. Hashmi NK, Ghadimi K, Srinivasan AJ, et al. Three-factor prothrombin complex concentrates for refractory bleeding after cardiovascular surgery within an algorithmic approach to haemostasis. Vox Sang. 2019;114:374-85.

101. Piacente C, Martucci G, Miceli V, et al. A narrative review of antithrombin use during veno-venous extracorporeal membrane oxygenation in adults: rationale, current use, effects on anticoagulation, and outcomes. Perfusion. 2020;267659120913803.

102. Kurihara C, Walter JM, Karim A, et al. Feasibility of veno-venous extracorporeal membrane oxygenation without systemic anticoagulation. Ann Thorac Surg 2020.

103. Chen L, Li Q, Zheng D, et al. Clinical Characteristics of Pregnant Women with Covid-19 in Wuhan. China N Engl J Med. 2020.

104. Dashraath P, Wong JL, Lim MXK, et al. Coronavirus disease 2019 (COVID-19) pandemic and pregnancy. Am J Obstet Gynecol. 2020;222:521-31.

105. Simcox LE, Ormesher L, Tower C, Greer IA. Thrombophilia and Pregnancy Complications. Int J Mol Sci. 2015;16:28418-28.

\section{Publisher's Note}

Springer Nature remains neutral with regard to jurisdictional claims in published maps and institutional affiliations.

\section{Ready to submit your research? Choose BMC and benefit from:}

- fast, convenient online submission

- thorough peer review by experienced researchers in your field

- rapid publication on acceptance

- support for research data, including large and complex data types

- gold Open Access which fosters wider collaboration and increased citations

- maximum visibility for your research: over $100 \mathrm{M}$ website views per year

At BMC, research is always in progress.

Learn more biomedcentral.com/submissions 